УДК 621.864.8

V. M. Korendiy

Lviv Polytechnic National University

\title{
SUBSTANTIATION OF PARAMETERS AND MOTION MODELLING OF TWO-MASS MOBILE VIBRATORY SYSTEM WITH TWO UNBALANCED VIBRATION EXCITERS
}

(C) Korendiy V. M., 2018

doi

The purpose of research. Analysis of influence of stiffness parameters of mobile vibratory device with two unbalanced vibration exciters on eigenfrequencies of its mechanical system and substantiation of stiffness parameters in order to ensure its energy-efficient resonance operation mode. Methodology. The technique of the research is based on fundamental concepts of engineering mechanics and theory of mechanical vibrations. In order to deduce the differential equations of motion of the mechanical system of mobile vibratory robot the d'Alambert-Lagrange principle was used. The computation modelling of the system's motion caused by periodic excitation forces was carried out using MathCAD software. Results. The design diagram (model) of the two-mass mobile vibratory system with two unbalanced vibration exciters was constructed. The mathematical model of its motion was developed and the parameters of the resonance mode of its operation were substantiated. In particular, the influence of stiffness parameters of mobile vibratory device with two unbalanced vibration exciters on eigenfrequencies of its mechanical system was analysed. The steady-state and transient conditions of operation of the system under the influence of periodic excitation force were investigated. Scientific novelty. The analytical dependencies for determination of stiffness parameters of the mechanical oscillating system of two-mass mobile vibratory device with two unbalanced vibration exciters were derived in order to ensure its operation in energy-efficient resonance mode. The value of the phase shift of the unbalanced exciters' rotation was substantiated in order to maximize the device's motion speed. Practical value. The results of the carried out investigations can be used while designing and developing control systems of mobile vibratory transporting and robotic devices in order to ensure the possibility of changing the speed of their motion without changing the frequency and direction of rotation of unbalanced vibration exciters.

Keywords: mobile vibratory system, vibration exciter, resonance operation mode, inertial parameters, stiffness parameters, excitation parameters, phase shift.

Introduction. Mobile robots are widely used for performing different transporting and technological operations in environments which are dangerous for human beings. Most of such systems are equipped by tracked or wheeled drives, and some models - by walking mechanisms. However, such robots can not be effectively used while performing rescuing operations among the debris of buildings where it is necessary to move through narrow gaps or while cleaning and diagnosing internal surfaces of long tubes and pipelines. That's why, nowadays, the new direction of mobile robotics is being developed [1-9]. This direction deals with vibratory robots which do not need specific drives (wheels, caterpillars, legs, screws etc.) and use the oscillatory motion of their working bodies interacting directly with environment for performing different transporting and technological operations.

That's why, the problems of investigating the dynamics of motion and substantiating the parameters of vibratory robots being considered as mobile mechanical systems, which can move in the prescribed environment due to the changes of their structures or periodic displacements of their internal masses, are urgent. In particular, in this paper, the possibilities of implementation of mobile vibratory devices based on two-mass oscillating systems with two unbalanced vibration exciters will be substantiated.

Analysis of modern information sources on the subject of research. Nowadays, there exists a great variety of mobile vibratory devices [1-9]. The simplest robots consist of one body being able to move along a straight line [1-4]. The more complicated structures have much greater amount of bodies and 
can move in different directions [5-9]. Planar motion can be ensured, for example, by changing the shape of the robot's body (snake-like motion), as well as by moving the internal masses in a plane parallel to the plane of motion of the robot [1]. In this article, we shall pay attention to 1-D robots, which can perform only straight-line motion.

One of the ways of providing the motion of 1-D robots consists in ensuring vibratory motion of internal masses in the direction of the motion of the robot $[1,4,5]$. This can be performed by rotation of unbalanced masses $[2,5,6,8]$, by piezoactuators [4, 7, 9], by electromagnets [1] etc. The first way of excitation of the oscillatory motion is the most interesting one from the point of view of the system's dynamics. Especially, when the mechanical system consists of two and more movable bodies. The problem of modelling vibratory system's dynamics becomes more complicated when the number of active actuators increases. This problem requires thorough analysis of the influences acting upon the working bodies including Coulomb's friction and viscous damping [10]. Herewith, it is necessary to mention that most mobile vibratory devices should be considered as semidefinite (unrestricted) mechanical oscillatory systems. Thus, in order to ensure their efficient operation, it is necessary to substantiate the inertial and stiffness parameters in such a way that the mechanical system is to be oscillating in resonance (nearresonance) mode. This assumption will be taken into account as a basic one while carrying out further investigations in this paper.

The purpose of research. The purpose of this paper consists in analysis of influence of stiffness parameters of mobile vibratory device with two unbalanced vibration exciters on eigenfrequencies of its mechanical system and in substantiation of stiffness parameters in order to ensure its energy-efficient resonance operation mode. Also, the parameters of the phase shift of the unbalanced exciters' rotation should be substantiated in order to maximize the device's motion speed.

The idea of operation of mobile vibratory device. In this paper, the possibilities of using twomass oscillatory system with two unbalanced vibration exciters as mobile transporting device with straightline motion of the working bodies will be substantiated. In further investigations, it is planned to consider the prospects of developing the controlled mobile vibratory systems based on the similar structure ensuring the possibility of motion in any direction of the supporting plane.

One of the simplest designs of mobile vibratory system is presented in Fig. 1. The mechanical system of the device consists of two bodies 1 and 2 connected by a coil cylindrical spring and placed on a stationary supporting surface 4 ensuring the possibility of straight-line motion (sliding) of the bodies. On each body, there are the corresponding hinges 9 and 10 to which the driving cranks 7 and 8 are attached. On the free edges of the cranks, the ball masses 5 and 6 are placed. These masses are considered as unbalanced exciters rotating about the hinges 9 and 10, and exerting the corresponding inertial loadings on the working masses 1 and 2 causing their motion.

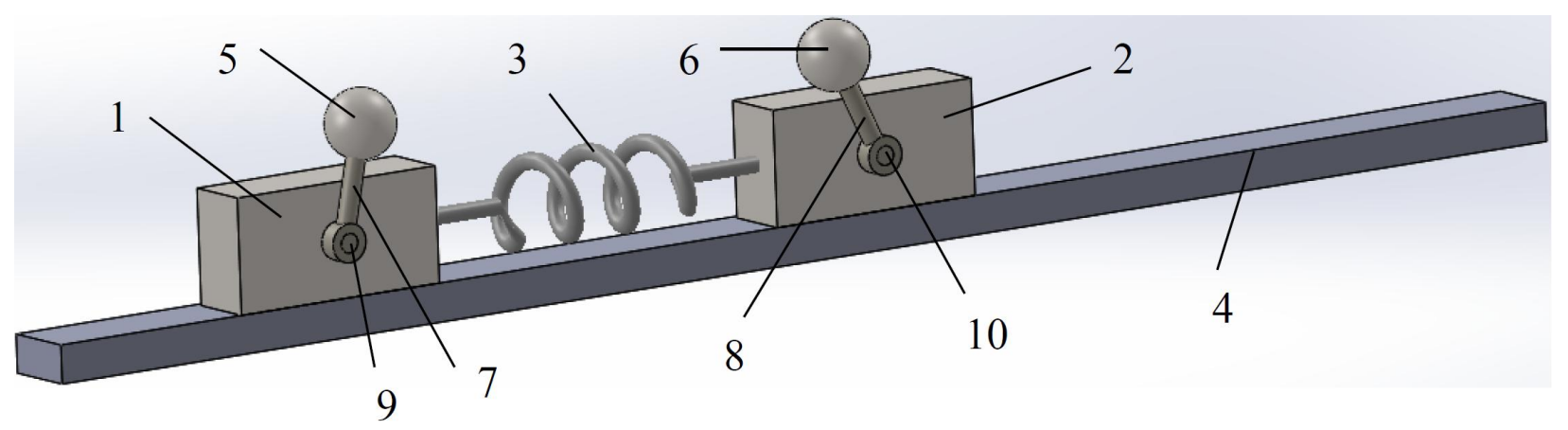

Fig. 1. Design diagram of mobile vibratory system with two unbalanced vibration exciters

Рис. 1. Розрахункова схема мобільної вібраційної системи з двома дебалансними віброзбудниками 
The motion of the system is carried out due to the action (exertion) of periodic variable centrifugal forces caused by rotation of unbalanced masses 5 and 6 upon corresponding working bodies 1 and 2 (Fig. 1). The kinematic characteristics of the system's motion, in particular, the speed of horizontal motion of the system's gravity centre, depend on the rotation frequencies of the unbalanced masses, their phase shift (initial angular position difference), as well as on inertial, stiffness and damping properties of the oscillating system and supporting surface.

In this paper, the preconditions of further investigation of influence of the mentioned parameters of the mobile vibratory system on its motion speed will be initiated. In particular, in the following paragraphs, the kinematic scheme of the device's mechanical oscillating system will be constructed, the mathematical model of the system's motion will be formed, its amplitude-frequency characteristics will be analysed, and the relationships between inertial, stiffness and damping parameters will be substantiated in order to ensure the resonance operation mode of the vibratory device.

Constructing the kinematic diagram and analysis of forces acting upon the elements of mechanical system. Let us consider the kinematic diagram of the mobile vibratory system presented in Fig. 2. The working masses $m_{1}$ and $m_{2}$ can move along horizontal axis $O x$ and are considered as rigid bodies (solids). To define the motion of each mass, the corresponding generalized coordinates $x_{1}$ and $x_{2}$ are used. While developing the mathematical model of the oscillating system and while carrying out further investigations let us neglect the geometrical sizes and shapes of the working bodies considering them as mass points (particles). Also let us assume that the bodies are connected by elastic-tough element characterised be stiffness $c$ and energy-dissipation coefficient (coefficient of tough resistance) $\mu$. While defining potential forces let us assume that deformations of the elastic element are performed in accordance with the linear Hooke's law.

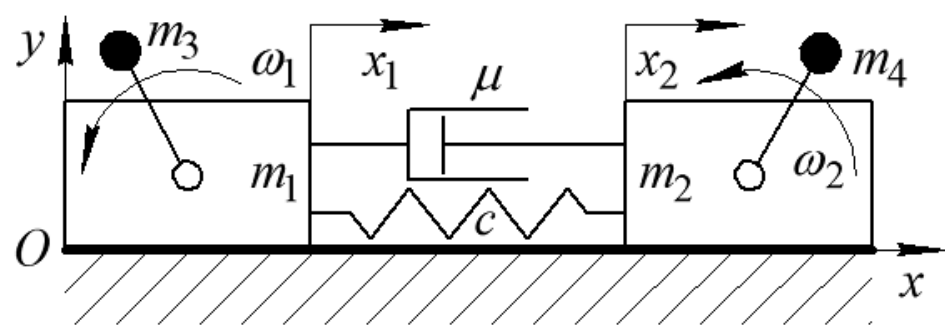

Fig. 2. Kinematic diagram of oscillating system of mobile vibratory device with two unbalanced vibration exciters

Рис. 2. Кінематична схема коливної системи мобільної вібраиійної установки з двома дебалансними віброзбудниками

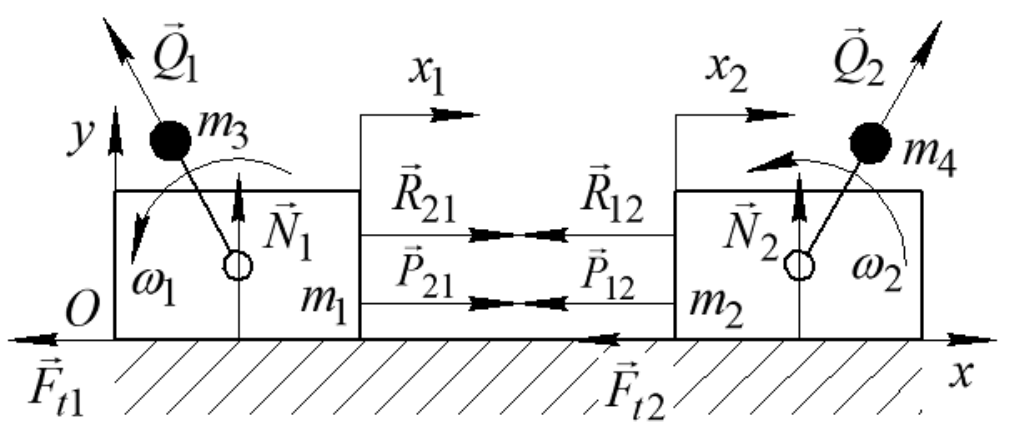

Fig. 3. Diagram of forces acting upon each mass of the oscillating system

Рис. 3. Схема сил, щуо діють на кожну з мас коливної системи 
The working masses of the oscillating system are acted by centrifugal forces $\dot{Q}_{1}$ and $\dot{Q}_{2}$ caused by rotation of unbalanced masses (Fig. 3). These forces are periodic variable forces and change their direction with circular frequencies $\omega_{1}$ and $\omega_{2}$, correspondingly. Also, the masses are influenced by alternating tensioncompression loads $\stackrel{P}{P}_{12}, \stackrel{P}{P}_{21}$ and tough resistance forces $\stackrel{1}{R}_{12}, \stackrel{R}{R}_{21}$ due to their connection by the elastic element. In addition, as a result of interaction of each mass with the supporting surface they are acted by friction forces $\dot{F}_{t 1}$ and $\dot{F}_{t 2}$ whose directions depend on the directions of motion of corresponding bodies.

As it has been mentioned previously, the alternating centrifugal forces $\stackrel{\prime}{Q}_{1}$ and $\stackrel{\prime}{Q}_{2}$ caused by rotation of unbalanced masses are considered as the driving (exciting, disturbing) forces. Due to defining the rational inertial and stiffness parameters of the oscillating system of mobile vibratory device and the excitation parameters (rotation frequencies and phase shift of unbalanced masses), it is possible to ensure the translational motion of mobile robot in any direction of the axis $O x$. For this, it is necessary to derive the differential equations of motion of mechanical oscillating system of the robot with further plotting of amplitude-frequency characteristics and determination of optimal operation modes of vibratory device.

Formation of mathematical model of the system's motion. In order to derive the differential equations of motion of the vibratory device's mechanical system let us use the d'Alambert-Lagrange principle. This principle can be stated as follows: if the system is moving, the active forces, reactions of constraints and inertial forces form an equilibrated (balanced) system of forces for each particle of the system. For the considered mechanical system with two working masses the d'Alambert-Lagrange principle can be presented in the following vector form:

$$
\sum_{k=1}^{2}{\underset{F}{k}}_{k}+\sum_{k=1}^{2} \underset{R_{k}}{\operatorname{ur}}+\sum_{k=1}^{2}{\underset{\Phi}{\Phi}}_{k}=0
$$

where $\sum_{k=1}^{2} \vec{F}_{k}$ is the sum of resultants of all active forces applied to each point of the mechanical system; $\sum_{k=1}^{2} R_{k}$ is the sum of resultants of the constraints' reactions exerted on each particle of the mechanical system; $\sum_{k=1}^{2}{\underset{\Phi}{k}}_{k}$ is the sum of inertial forces acting upon each particle of the mechanical system.

As a result of projecting the equation (1) for each particle of the system on the axes of rectangular coordinate system, we obtain the following system of equations:

$$
\left\{\begin{array}{l}
F_{1 x}+R_{1 x}+\Phi_{1 x}=0 \\
F_{2 x}+R_{2 x}+\Phi_{2 x}=0 \\
F_{1 y}+R_{1 y}+\Phi_{1 y}=0 \\
F_{2 y}+R_{2 y}+\Phi_{2 y}=0
\end{array}\right.
$$

Taking into account the material presented above, let us write the corresponding expressions for determining the active forces and constraints' reactions acting upon the particles of the mechanical system. The inertial forces acting upon the working bodies of the mechanical oscillating system are equal to the product of their masses on the corresponding projections of accelerations. Taking into account the fact that the bodies cannot move in vertical direction, we obtain:

$$
\Phi_{1 x}=-\left(m_{1}+m_{3}\right) \cdot \Phi_{2 x}=-\left(m_{2}+m_{4}\right) ; \quad \Phi_{1 y}=0 ; \quad \Phi_{2 y}=0 .
$$

In this case, as a constraint we consider the rough surface which is characterized by the corresponding friction forces $F_{t 1}, F_{t 2}$ (Fig. 3) and normal reactions $N_{1}, N_{2}$. Hence, in order to determine the reactions of constraints in equations (2), let us use the following formulas: 


$$
\begin{aligned}
& R_{1 x}=F_{t 1}=-f_{1} \cdot N_{1} \cdot \operatorname{sign}(q) ; \\
& R_{2 x}=F_{t 2}=-f_{2} \cdot N_{2} \cdot \operatorname{sign}\left(\frac{1}{2}\right) ; \\
& R_{1 y}=N_{1} ; \quad R_{2 y}=N_{2},
\end{aligned}
$$

where $\operatorname{sign}(\$)$ is the function which defines the direction of motion of the corresponding body $(i=\overline{1,2})$ :

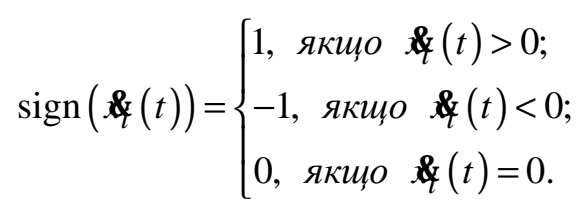

Active forces acting upon the particles of the mechanical system can be divided into gravitational ones $\left(F_{g r 1}, F_{g r 2}\right)$, exciting ones (inertial forces caused by unbalanced masses rotation) $\left(Q_{1}, Q_{2}\right)$, elastic and dissipative ones (applied as a result of tension/compression of the elastic element between the working bodies) $\left(F_{p r 1}, F_{p r 2}\right)$ :

$$
\begin{array}{ll}
F_{1 x}=-F_{g r 1}+Q_{1 x}+F_{p r 1 x} ; & F_{2 x}=-F_{g r 2}+Q_{2 x}+F_{p r 2 x} ; \\
F_{1 y}=-F_{g r 1}+Q_{1 y}+F_{p r 1 y} ; & F_{2 y}=-F_{g r 2}+Q_{2 y}+F_{p r 2 y} .
\end{array}
$$

The gravitational forces act only in vertical direction:

$$
F_{g r 1 x}=0 ; \quad F_{g r 2 x}=0 ; \quad F_{g r 1 y}=\left(m_{1}+m_{3}\right) \cdot g ; \quad F_{g r 2 y}=\left(m_{2}+m_{4}\right) \cdot g,
$$

where $g$ is free fall acceleration.

The excitation of oscillation of the mechanical system is performed due to the rotation of the unbalanced masses. Herewith, the direction of the excitation force action is being changed in time. For deriving the differential equations of motion of the mechanical oscillating system, in further investigations let us consider constant frequency of the unbalanced masses' rotation. This assumption allows us to write the following expressions for inertial forces:

$$
\begin{array}{ll}
Q_{1 x}=m_{3} \cdot l_{1} \cdot \omega_{1}^{2} \cdot \cos \left(\xi_{1}+\omega_{1} \cdot t\right) ; & Q_{2 x}=m_{4} \cdot l_{2} \cdot \omega_{2}^{2} \cdot \cos \left(\xi_{2}+\omega_{2} \cdot t\right) ; \\
Q_{1 y}=m_{3} \cdot l_{1} \cdot \omega_{1}^{2} \cdot \sin \left(\xi_{1}+\omega_{1} \cdot t\right) ; & Q_{2 y}=m_{4} \cdot l_{2} \cdot \omega_{2}^{2} \cdot \sin \left(\xi_{2}+\omega_{2} \cdot t\right),
\end{array}
$$

where $l_{i}$ is the length of the crank of the $i$-th unbalanced mass; $\xi_{i}$ is the initial phase of oscillations of the $i$-th unbalanced mass (the initial angle of inclination of the unbalanced mass's crank with respect to the $O x$ axis).

Elastic and dissipative forces occurring as a result of tension/compression of the elastic element between the working bodies depend on the relative position of the bodies and the difference between their linear velocities. While deriving the analytical dependencies for determining elastic and dissipative forces, let us assume the following: the deformations of the elastic element are performed in accordance with the linear Hook's law, and the coefficient of viscous friction (damping coefficient) is proportional to the velocity of the spring's deforming. Thus, in order to determine the elastic and dissipative forces we obtain the following expression:

$$
\begin{gathered}
F_{p r 1 x}=-\left(c \cdot\left(x_{1}-x_{2}\right)+\mu \cdot(-2)\right) ; \quad F_{p r 2 x}=-\left(c \cdot\left(x_{2}-x_{1}\right)+\mu \cdot(q-1)\right) ; \\
F_{p r 1 y}=0 ; \quad F_{p r 2 y}=0,
\end{gathered}
$$

where $c$ is the stiffness coefficient of the elastic element; $\mu$ is the damping coefficient (coefficient of viscous friction) of the elastic element.

Taking into account the equations (5)-(8), the general expression for determining the active forces acting upon each particle of the mechanical system is as follows:

$$
F_{1 x}=m_{3} \cdot l_{1} \cdot \omega_{1}^{2} \cdot \cos \left(\xi_{1}+\omega_{1} \cdot t\right)-\left(c \cdot\left(x_{1}-x_{2}\right)+\mu \cdot\left(\alpha-\alpha_{2}\right)\right) ;
$$




$$
F_{2 x}=m_{4} \cdot l_{2} \cdot \omega_{2}^{2} \cdot \cos \left(\xi_{2}+\omega_{2} \cdot t\right)-\left(c \cdot\left(x_{2}-x_{1}\right)+\mu \cdot(x)\right) .
$$

Taking into account the equations (2), (3), (4), (9), according to the d'Alambert-Lagrange principle, the general form of differential equations of the mechanical oscillating system's motion of the mobile vibratory device is as follows:

$$
\begin{aligned}
& \left(m_{1}+m_{3}\right) \cdot\left[\begin{array}{l}
m_{3} \cdot l_{1} \cdot \omega_{1}^{2} \cdot \cos \left(\xi_{1}+\omega_{1} \cdot t\right)-\left(c \cdot\left(x_{1}-x_{2}\right)+\mu \cdot\left(\alpha_{1}\right)\right)- \\
-f_{1} \cdot\left(\left(m_{1}+m_{3}\right) \cdot g-m_{3} \cdot l_{1} \cdot \omega_{1}^{2} \cdot \sin \left(\xi_{1}+\omega_{1} \cdot t\right)\right) \cdot \operatorname{sign}\left(\alpha_{1}\right)
\end{array}\right] ;
\end{aligned}
$$

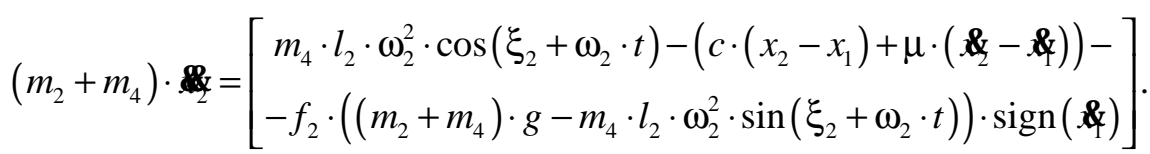

Determination of natural frequencies of free oscillations of the system. In order to deduce analytical dependencies for determining eigenfrequencies of the vibratory device's natural oscillations let us write the system (10) of differential equations of its motion in the normal form: all the terms of the equations consisting of derivatives are transposed to the left sides of the equations, and the terms without derivatives - to the right sides:

$$
\begin{aligned}
& \left(m_{1}+m_{3}\right) \cdot \mu \cdot(\alpha-\alpha)+c \cdot\left(x_{1}-x_{2}\right)=P_{1}(t) ; \\
& \left(m_{2}+m_{4}\right) \cdot \mu \cdot(\mathbf{q})+c \cdot\left(x_{2}-x_{1}\right)=P_{2}(t),
\end{aligned}
$$

where $\quad P_{1}(t)=m_{3} \cdot l_{1} \cdot \omega_{1}^{2} \cdot \cos \left(\xi_{1}+\omega_{1} \cdot t\right)-f_{1} \cdot\left(\left(m_{1}+m_{3}\right) \cdot g-m_{3} \cdot l_{1} \cdot \omega_{1}^{2} \cdot \sin \left(\xi_{1}+\omega_{1} \cdot t\right)\right) \cdot \operatorname{sign}(\alpha)$; $P_{2}(t)=m_{4} \cdot l_{2} \cdot \omega_{2}^{2} \cdot \cos \left(\xi_{2}+\omega_{2} \cdot t\right)-f_{2} \cdot\left(\left(m_{2}+m_{4}\right) \cdot g-m_{4} \cdot l_{2} \cdot \omega_{2}^{2} \cdot \sin \left(\xi_{2}+\omega_{2} \cdot t\right)\right) \cdot \operatorname{sign}(\propto)$.

The obtained system (11) is a system of linear inhomogeneous differential equations of the second order with constant coefficients. In order to determine eigenfrequencies of the mechanical system it is necessary to define the general solutions of the corresponding system of homogeneous equations:

$$
\begin{aligned}
& \left(m_{1}+m_{3}\right) \cdot \mu \cdot(\alpha-\alpha)+c \cdot\left(x_{1}-x_{2}\right)=0 ; \\
& \left(m_{2}+m_{4}\right) \cdot \mu \cdot(\alpha-c)+\left(x_{2}-x_{1}\right)=0,
\end{aligned}
$$

or

$$
\begin{aligned}
& +\frac{\mu}{m_{1}+m_{3}} \cdot(1)+\frac{c}{m_{1}+m_{3}} \cdot\left(x_{1}-x_{2}\right)=0 ; \\
& +\frac{\mu}{m_{2}+m_{4}} \cdot\left(x-\frac{c}{m_{2}+m_{4}} \cdot\left(x_{2}-x_{1}\right)=0,\right.
\end{aligned}
$$

or

$$
\begin{aligned}
& +2 \cdot n_{1} \cdot d-2 \cdot n_{1} \cdot k_{1}^{2} \cdot x_{1}-k_{1}^{2} \cdot x_{2}=0 ; \\
& +2 \cdot n_{2} \cdot 2 \cdot n_{2} \cdot \alpha+k_{2}^{2} \cdot x_{2}-k_{2}^{2} \cdot x_{1}=0,
\end{aligned}
$$

where $n_{1}=\frac{\mu}{2 \cdot\left(m_{1}+m_{3}\right)} ; n_{2}=\frac{\mu}{2 \cdot\left(m_{2}+m_{4}\right)} ; k_{1}=\sqrt{\frac{c}{m_{1}+m_{3}}} ; k_{2}=\sqrt{\frac{c}{m_{2}+m_{4}}}$.

In order to solve the obtained system of differential equations let us use the Euler's method, which states that roots of the corresponding equations can be determined in the following form:

$$
x_{1}=X_{1} \cdot e^{\lambda t} ; \quad x_{2}=X_{2} \cdot e^{\lambda t},
$$

where $X_{1}, X_{2}, \lambda$ are unknown constants which can be determined in terms of given initial conditions.

Let us take the corresponding derivatives of equations (13) with respect to time:

$$
\begin{aligned}
& \propto=X_{1} \cdot \lambda \cdot e^{\lambda t} ; \quad X_{2} \cdot \lambda \cdot e^{\lambda t} ; \\
& \&=X_{1} \cdot \lambda^{2} \cdot e^{\lambda t} ; \quad X_{2} \cdot \lambda^{2} \cdot e^{\lambda t},
\end{aligned}
$$



obtain:

Substituting expressions (13) and (14) into the system of equations (12) and cancelling $e^{\lambda t}$, we

$$
\begin{aligned}
& X_{1} \cdot \lambda^{2}+2 \cdot n_{1} \cdot X_{1} \cdot \lambda-2 \cdot n_{1} \cdot X_{2} \cdot \lambda+k_{1}^{2} \cdot X_{1}-k_{1}^{2} \cdot X_{2}=0 \\
& X_{2} \cdot \lambda^{2}+2 \cdot n_{2} \cdot X_{2} \cdot \lambda-2 \cdot n_{2} \cdot X_{1} \cdot \lambda+k_{2}^{2} \cdot X_{2}-k_{2}^{2} \cdot X_{1}=0 .
\end{aligned}
$$

Let us reduce the obtained system (15) of linear algebraic equations with constant coefficients to the normal form with respect to the constants $X_{1}, X_{2}$ :

$$
\begin{aligned}
& \left(\lambda^{2}+2 \cdot n_{1} \cdot \lambda+k_{1}^{2}\right) \cdot X_{1}-\left(2 \cdot n_{1} \cdot \lambda+k_{1}^{2}\right) \cdot X_{2}=0 \\
& -\left(2 \cdot n_{2} \cdot \lambda+k_{2}^{2}\right) \cdot X_{1}+\left(\lambda^{2}+2 \cdot n_{2} \cdot \lambda+k_{2}^{2}\right) \cdot X_{2}=0 .
\end{aligned}
$$

The constants $X_{1}, X_{2}$ are not equal to zero only in the case when the determinant of the system (16) is equal to zero:

$$
\left|\begin{array}{cc}
\lambda^{2}+2 \cdot n_{1} \cdot \lambda+k_{1}^{2} & -\left(2 \cdot n_{1} \cdot \lambda+k_{1}^{2}\right) \\
-\left(2 \cdot n_{2} \cdot \lambda+k_{2}^{2}\right) & \lambda^{2}+2 \cdot n_{2} \cdot \lambda+k_{2}^{2}
\end{array}\right|=0 .
$$

The equation (17) is a characteristic equation for the system (12). It may be reduced to the quartic equation with respect to $\lambda$ :

$$
\lambda^{4}+\left(2 \cdot n_{1}+2 \cdot n_{2}\right) \cdot \lambda^{3}+\left(k_{1}^{2}+k_{2}^{2}\right) \cdot \lambda^{2}=0
$$

The roots of the equation (18) are as follows:

$$
\lambda_{1,2}=0 ; \quad \lambda_{3,4}= \pm \sqrt{\left(n_{1}+n_{2}\right)^{2}-\left(k_{1}^{2}+k_{2}^{2}\right)}-\left(n_{1}+n_{2}\right)
$$

The equations (19) allows us to determine the eigenfrequencies of the mechanical system's free oscillations. The following formulas presents the expressions for calculating undamped natural frequency (frequency of undamped free oscillations) $\omega_{0}$ and damped natural frequency (frequency of damped free oscillations for the case of the underdamped system) $\omega_{d}$ :

$$
\begin{aligned}
& \omega_{0_{1}}=\omega_{d_{1}}=0 \\
& \omega_{0_{2}}=\sqrt{k_{1}^{2}+k_{2}^{2}}=\sqrt{\left(\sqrt{\frac{c}{m_{1}+m_{3}}}\right)^{2}+\left(\sqrt{\frac{c}{m_{2}+m_{4}}}\right)^{2}}=\sqrt{\frac{c \cdot\left(m_{1}+m_{3}+m_{2}+m_{4}\right)}{\left(m_{1}+m_{3}\right) \cdot\left(m_{2}+m_{4}\right)}} \\
& \omega_{d_{2}}=\sqrt{\left(k_{1}^{2}+k_{2}^{2}\right)-\left(n_{1}+n_{2}\right)^{2}}= \\
& =\sqrt{\left(\left(\sqrt{\frac{c}{m_{1}+m_{3}}}\right)^{2}+\left(\sqrt{\frac{c}{m_{2}+m_{4}}}\right)^{2}\right)-\left(\frac{\mu}{2 \cdot\left(m_{1}+m_{3}\right)}+\frac{\mu}{2 \cdot\left(m_{2}+m_{4}\right)}\right)^{2}}= \\
& =\sqrt{\frac{c \cdot\left(m_{1}+m_{3}+m_{2}+m_{4}\right)}{\left(m_{1}+m_{3}\right) \cdot\left(m_{2}+m_{4}\right)}-\left(\frac{\mu \cdot\left(m_{1}+m_{3}+m_{2}+m_{4}\right)}{2 \cdot\left(m_{1}+m_{3}\right) \cdot\left(m_{2}+m_{4}\right)}\right)^{2}} .
\end{aligned}
$$

One of the natural frequencies of the system is zero $\left(\omega_{0_{1}}=\omega_{d_{1}}=0\right)$, which means that the mechanical system is not vibrating. In other words, the mechanical system consisting of two rigid bodies moves as a whole (one body) without any relative motion between the two masses. Thus, the systems being investigated can be considered as a semidefinite (unrestricted) systems, because they have one of the natural frequencies equal to zero. Let us consider the case of force-damped vibrations of the presented semidefinite vibratory system and find the steady-state solutions of the equations (11). 
Analysis of forced-damped oscillations of vibratory device. Considering the forced-damped vibrations of the considered device, the equations (11) of motion of its two-degree-of-freedom system under the action of external forces can be written as:

$$
\left(\begin{array}{cc}
m_{1}+m_{3} & 0 \\
0 & m_{2}+m_{4}
\end{array}\right) \cdot\left(\begin{array}{l} 
\\
4
\end{array}\right)+\mu \cdot\left(\begin{array}{l}
x_{1}-x_{2} \\
x_{2}-x_{1}
\end{array}\right)=\left(\begin{array}{l}
P_{1} \\
P_{2}
\end{array}\right) .
$$

Let us consider the external forces to be harmonic neglecting the dry-friction damping. This assumption can be substantiated be the following fact. If the dry-friction force is small compared to the amplitudes of the active forces $Q_{1 x}, Q_{2 x}$, the steady-state solution is expected to be nearly harmonic. Thus, we obtain:

$$
P_{j}=P_{j 0} \cdot e^{i \omega t}, \quad j=1,2
$$

where $\omega$ is the forcing frequency.

We can write the steady-state solutions as:

$$
x_{j}=X_{j} \cdot e^{i \omega t}, \quad j=1,2,
$$

where $X_{1}, X_{2}$ are complex quantities that depend on $\omega$ and on inertial, stiffness and damping parameters of the mechanical system.

Substitution of (23) and (22) into (21) leads to:

$$
\left(\begin{array}{cc}
-\omega^{2} \cdot\left(m_{1}+m_{3}\right)+i \cdot \omega \cdot \mu+c & i \cdot \omega \cdot \mu+c \\
i \cdot \omega \cdot \mu+c & -\omega^{2} \cdot\left(m_{2}+m_{4}\right)+i \cdot \omega \cdot \mu+c
\end{array}\right) \cdot\left(\begin{array}{l}
X_{1} \\
X_{2}
\end{array}\right)=\left(\begin{array}{l}
P_{10} \\
P_{20}
\end{array}\right)
$$

Let us define the mechanical impedance in the matrix form as:

$$
\begin{aligned}
{[Z(i \cdot \omega)]=Z_{r s}(i \cdot \omega) } & =\left(\begin{array}{cc}
-\omega^{2} \cdot\left(m_{1}+m_{3}\right)+i \cdot \omega \cdot \mu+c & i \cdot \omega \cdot \mu+c \\
i \cdot \omega \cdot \mu+c & -\omega^{2} \cdot\left(m_{2}+m_{4}\right)+i \cdot \omega \cdot \mu+c
\end{array}\right) \\
& =\left(\begin{array}{ll}
Z_{11}(i \cdot \omega) & Z_{12}(i \cdot \omega) \\
Z_{21}(i \cdot \omega) & Z_{22}(i \cdot \omega)
\end{array}\right), \quad r, s=1,2 .
\end{aligned}
$$

Let us reduce the equation (24) to the following form:

where $\stackrel{r}{X}=\left(\begin{array}{l}X_{1} \\ X_{2}\end{array}\right) ; \stackrel{r}{P_{0}}=\left(\begin{array}{l}P_{10} \\ P_{20}\end{array}\right)$

$$
[Z(i \cdot \omega)] \cdot \stackrel{+}{X}=\stackrel{\prime}{P}_{0}
$$

Let us solve the equation (26) and obtain ${ }^{\prime}$ :

$$
\stackrel{r}{X}=[Z(i \cdot \omega)]^{-1} \cdot \stackrel{r}{P_{0}}
$$

where the inverse of the impedance matrix is given by

$$
[Z(i \cdot \omega)]^{-1}=\frac{1}{Z_{11}(i \cdot \omega) \cdot Z_{22}(i \cdot \omega)-Z_{12}(i \cdot \omega) \cdot Z_{21}(i \cdot \omega)} \cdot\left(\begin{array}{cc}
Z_{22}(i \cdot \omega) & -Z_{12}(i \cdot \omega) \\
-Z_{21}(i \cdot \omega) & Z_{11}(i \cdot \omega)
\end{array}\right) .
$$

Equations (27) and (28) lead to the following solutions:

$$
\begin{aligned}
& X_{1}(i \cdot \omega)=\frac{Z_{22}(i \cdot \omega) \cdot P_{10}-Z_{12}(i \cdot \omega) \cdot P_{20}}{Z_{11}(i \cdot \omega) \cdot Z_{22}(i \cdot \omega)-Z_{12}(i \cdot \omega) \cdot Z_{21}(i \cdot \omega)} \\
& X_{2}(i \cdot \omega)=\frac{-Z_{21}(i \cdot \omega) \cdot P_{10}+Z_{11}(i \cdot \omega) \cdot P_{20}}{Z_{11}(i \cdot \omega) \cdot Z_{22}(i \cdot \omega)-Z_{12}(i \cdot \omega) \cdot Z_{21}(i \cdot \omega)} .
\end{aligned}
$$

By substituting the values of components of the impedance matrix (25) into (29), we can get the analytical dependencies of the amplitudes of the oscillating masses on the working frequency (or in the other words, the steady-state solution of the system (21)): 


$$
\begin{aligned}
& X_{1}(i \cdot \omega)=\frac{\left(-\omega^{2} \cdot\left(m_{2}+m_{4}\right)+i \cdot \omega \cdot \mu+c\right) \cdot F_{10}-(i \cdot \omega \cdot \mu+c) \cdot F_{20}}{\left(-\omega^{2} \cdot\left(m_{1}+m_{3}\right)+i \cdot \omega \cdot \mu+c\right) \cdot\left(-\omega^{2} \cdot\left(m_{2}+m_{4}\right)+i \cdot \omega \cdot \mu+c\right)-(i \cdot \omega \cdot \mu+c)^{2}} \\
& X_{2}(i \cdot \omega)=\frac{-(i \cdot \omega \cdot \mu+c) \cdot F_{10}+\left(-\omega^{2} \cdot\left(m_{1}+m_{3}\right)+i \cdot \omega \cdot \mu+c\right) \cdot F_{20}}{\left(-\omega^{2} \cdot\left(m_{1}+m_{3}\right)+i \cdot \omega \cdot \mu+c\right) \cdot\left(-\omega^{2} \cdot\left(m_{2}+m_{4}\right)+i \cdot \omega \cdot \mu+c\right)-(i \cdot \omega \cdot \mu+c)^{2}} .
\end{aligned}
$$

By substituting the equation (30) into (23), we can find the complete solution $x_{1}(t), x_{2}(t)$ :

$$
\begin{aligned}
& x_{1}(t)=\frac{\left(-\omega^{2} \cdot\left(m_{2}+m_{4}\right)+i \cdot \omega \cdot \mu+c\right) \cdot F_{10}-(i \cdot \omega \cdot \mu+c) \cdot F_{20}}{\left(-\omega^{2} \cdot\left(m_{1}+m_{3}\right)+i \cdot \omega \cdot \mu+c\right) \cdot\left(-\omega^{2} \cdot\left(m_{2}+m_{4}\right)+i \cdot \omega \cdot \mu+c\right)-(i \cdot \omega \cdot \mu+c)^{2}} \cdot e^{i \omega t} ; \\
& x_{2}(t)=\frac{-(i \cdot \omega \cdot \mu+c) \cdot F_{10}+\left(-\omega^{2} \cdot\left(m_{1}+m_{3}\right)+i \cdot \omega \cdot \mu+c\right) \cdot F_{20}}{\left(-\omega^{2} \cdot\left(m_{1}+m_{3}\right)+i \cdot \omega \cdot \mu+c\right) \cdot\left(-\omega^{2} \cdot\left(m_{2}+m_{4}\right)+i \cdot \omega \cdot \mu+c\right)-(i \cdot \omega \cdot \mu+c)^{2}} \cdot e^{i \omega t} .
\end{aligned}
$$

Substantiation of stiffness parameters of vibratory device in order to ensure the energy-efficient resonance operation mode. In order to correctly match the inertial and stiffness parameters of the vibratory device and to ensure energy-efficient resonance operation mode let us investigate the dependence of the stiffness of the elastic element on the oscillating system's eigenfrequency in the case when the mases of the working bodies and the lengths of the driving cranks are known: $m_{1}=m_{2}=0.25 \mathrm{~kg}$, $m_{3}=m_{4}=0.025 \mathrm{~kg}, l_{1}=l_{2}=0,03 \mathrm{~m}$. In order to simplify further calculations, let us neglect the coefficient of viscous damping in the elastic element $\mu \approx 0$. Adopting the stiffness of the elastic element varying from $0 \mathrm{~N} / \mathrm{m}$ to $15000 \mathrm{~N} / \mathrm{m}$, with a help of formula (20), let us construct the graphical dependence (Fig. 4) of the system's eigenfrequency on the stiffness of the connecting spring.

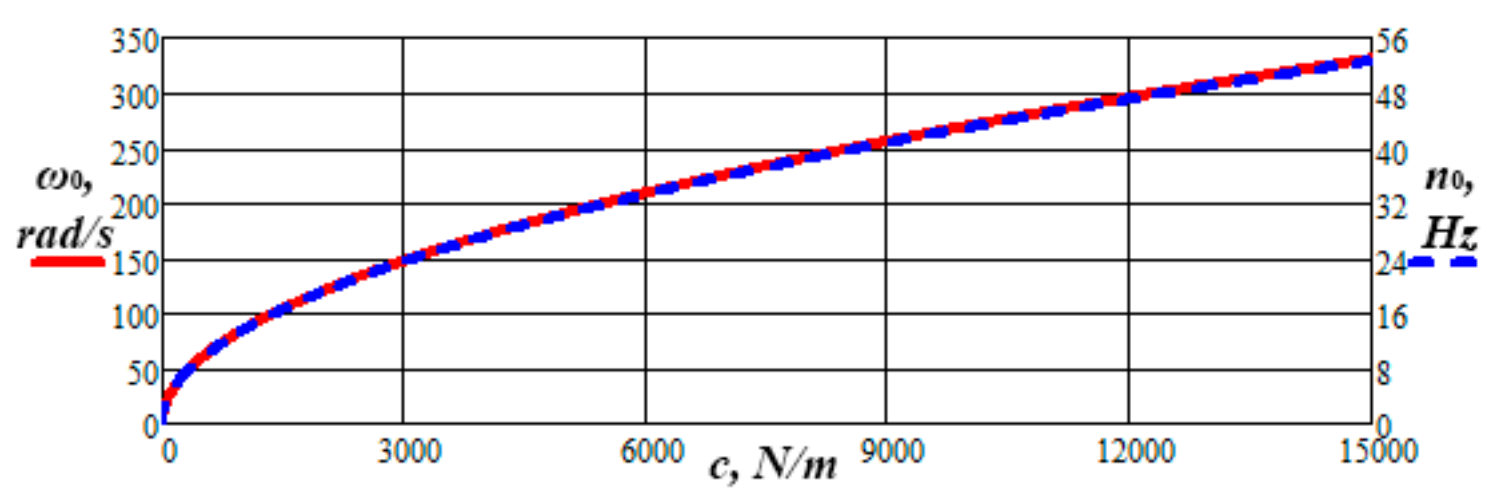

Fig. 4. Dependence of the oscillating system's eigenfrequency on the stiffness of the elastic element

Рис. 4. Залежність власної частоти коливної системи від жорсткості пружного елемента

By analysing the obtained plot (Fig. 4), we can mention the nonlinear proportional dependence of the oscillating system's eigenfrequency on the stiffness of the elastic element. For instance, in further investigations, let us adopt the following frequency of the excitation force (frequency of the unbalanced masses' rotation) $n_{1}=n_{2}=1500 \mathrm{rpm}=25 \mathrm{rev} / \mathrm{s}=25 \mathrm{~Hz}$. Thus, the forcing circular frequency is equal to $\omega_{1}=\omega_{2}=\frac{\pi \cdot n_{1}}{30}=\frac{3.14 \cdot 1500}{30}=157 \mathrm{rad} / \mathrm{s}$. Taking into account the necessity of the system's setting up on the resonance mode with the corresponding correction coefficient $z=0.96$, let us determine the necessary eigenfrequency of the oscillating system: 


$$
\omega_{0}=\frac{\omega_{1}}{z}=\frac{157}{0.96} \approx 163.6 \mathrm{rad} / \mathrm{s} .
$$

Thus, the determined eigenfrequency of the mechanical system of the vibratory device ensures the energy-efficient operation mode close to resonance one. In this case, according to the formula (20) and Fig. 4 , it is necessary to calculate the necessary stiffness of the elastic element:

$$
\begin{gathered}
c=\frac{\left(m_{1}+m_{3}\right) \cdot\left(m_{2}+m_{4}\right) \cdot \omega_{0}^{2}}{m_{1}+m_{2}+m_{3}+m_{4}}+\frac{\mu^{2} \cdot\left(m_{1}+m_{3}+m_{2}+m_{4}\right)}{4 \cdot\left(m_{1}+m_{3}\right) \cdot\left(m_{2}+m_{4}\right)}= \\
=\frac{(0.25+0.025) \cdot(0.25+0.025) \cdot 163.6^{2}}{0.25+0.025+0.25+0.025}+\frac{0^{2} \cdot(0.25+0.025+0.25+0.025)}{4 \cdot(0.25+0.025) \cdot(0.25+0.025)}=3680 \mathrm{~N} / \mathrm{m} .
\end{gathered}
$$

Taking into account the given inertial and force parameters, and using the determined stiffness of the connecting spring, with a help of the analytical dependencies (30), let us construct the amplitudefrequency characteristics (Fig. 5) of the oscillating system of the vibratory device.

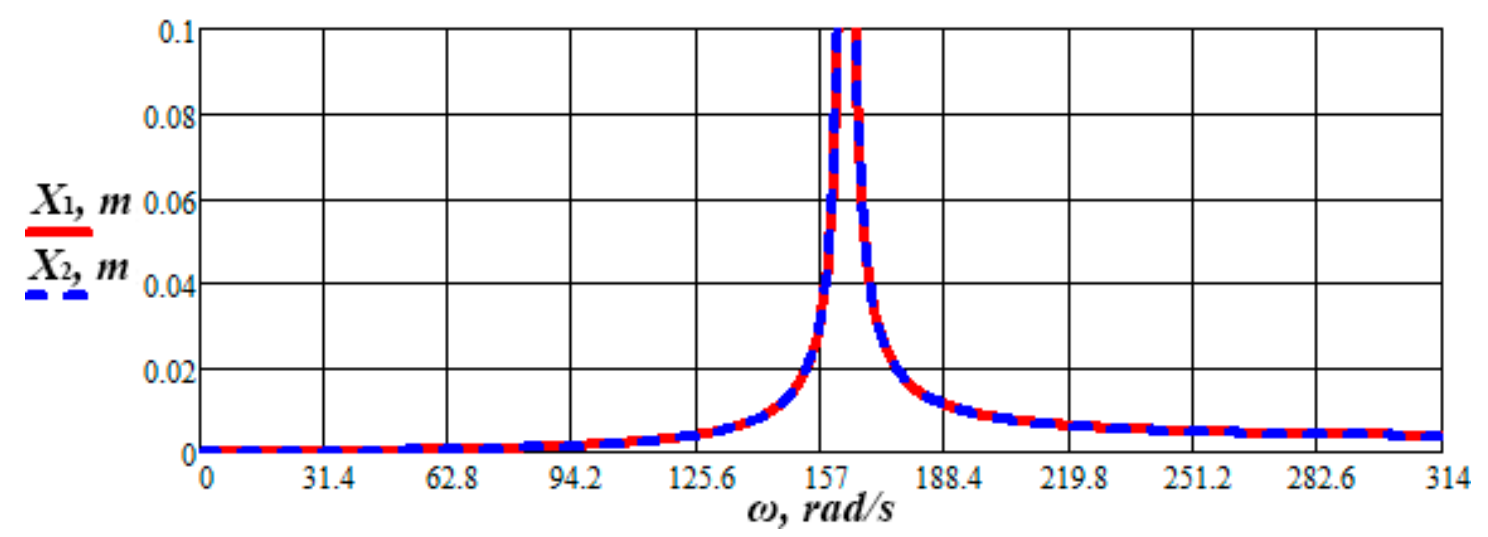

Fig. 5. Amplitude-frequency characteristic of the oscillating system

Рис. 5. Амплітудно-частотна характеристика коливної системи

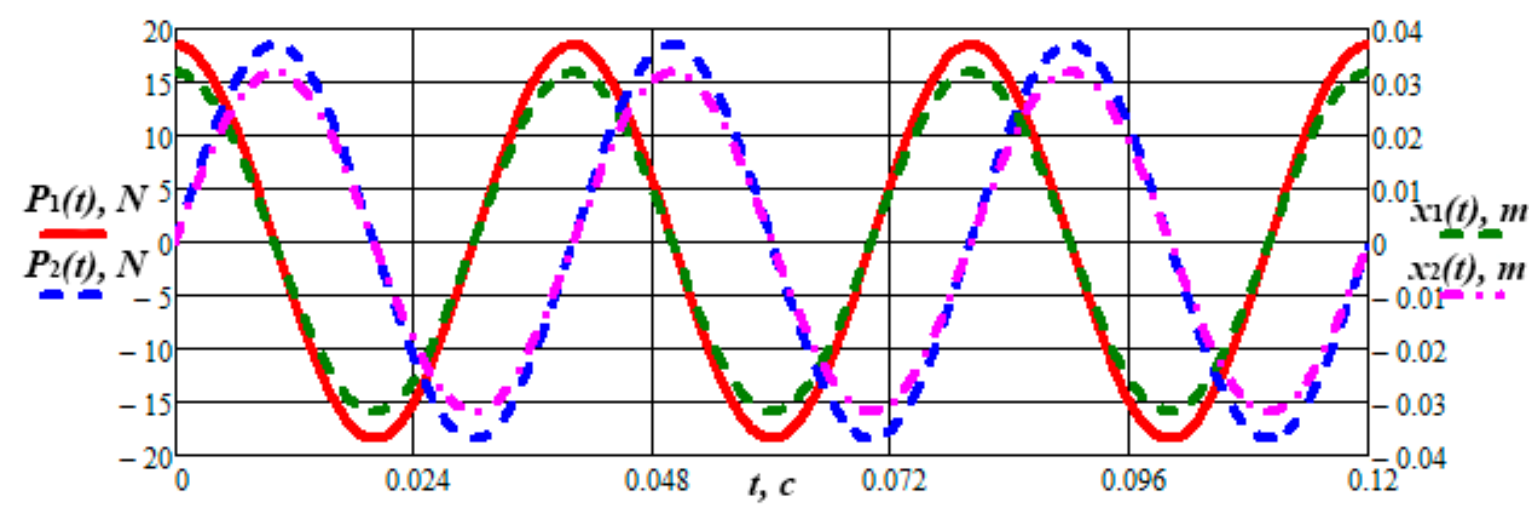

Fig. 6. Time-dependencies of changing the excitation forces and displacements of the oscillating masses from the equilibrium position in steady-state mode of the device's operation

Рис. 6. Часові залежності зміни збурювальних зусиль та відхилень коливних мас від положення рівноваги в усталеному режимі роботи установки

Let us construct the time dependence of the excitation force (Fig. 6) using the expressions (7). Also let us plot the corresponding time dependence of steady-state motion of the oscillating masses (Fig. 6) with a help of formulas (31). By analysing the obtained results, we can state that the excitation force $P_{1}(t)$ is characterized by the amplitude value of $18.5 \mathrm{~N}$ and changes in accordance with the cosine law with the frequency of $25 \mathrm{~Hz}$. The excitation force $P_{2}(t)$ is characterized by the same amplitude and frequency, but 
it changes in accordance with the sine law. In further investigations, it will be substantiated that the phase shift of $\pi / 2$ between the excitation forces $P_{1}(t)$ and $P_{2}(t)$ allows ensuring the most effective motion of the mobile vibratory system (i.e. the maximal motion speed). The maximal (amplitude) values of the oscillating masses' displacement from the equilibrium positions are following: $X_{1}=X_{2}=0,032 \mathrm{~m}$.

Numerical solving the differential equations of the system's motion in MathCAD software. Let us simulate the motion of the mobile vibratory device which is described by the system (10) of two linear nonhomogeneous differential equations of the second order with constant coefficients. In order to find the solution of the mentioned system ley us use the RADAUS method of MathCAD software.

The input parameters of the system being investigated are the following ones:

- inertial parameters: $m_{1}=m_{2}=0,25 \mathrm{~kg}, m_{3}=m_{4}=0,025 \mathrm{~kg}, l_{1}=l_{2}=0,03 \mathrm{~m}$;

- stiffness parameters: $c=3681 \mathrm{~N} / \mathrm{m}$;

- damping and friction parameters are to be neglected in order to simplify the process of the equations' solving: $\mu=0, f_{1}=f_{2}=0$.

Table 1

The investigated phases of the unbalanced masses rotation

Таблищя 1

\section{Досліджувані фази обертань дебалансів}

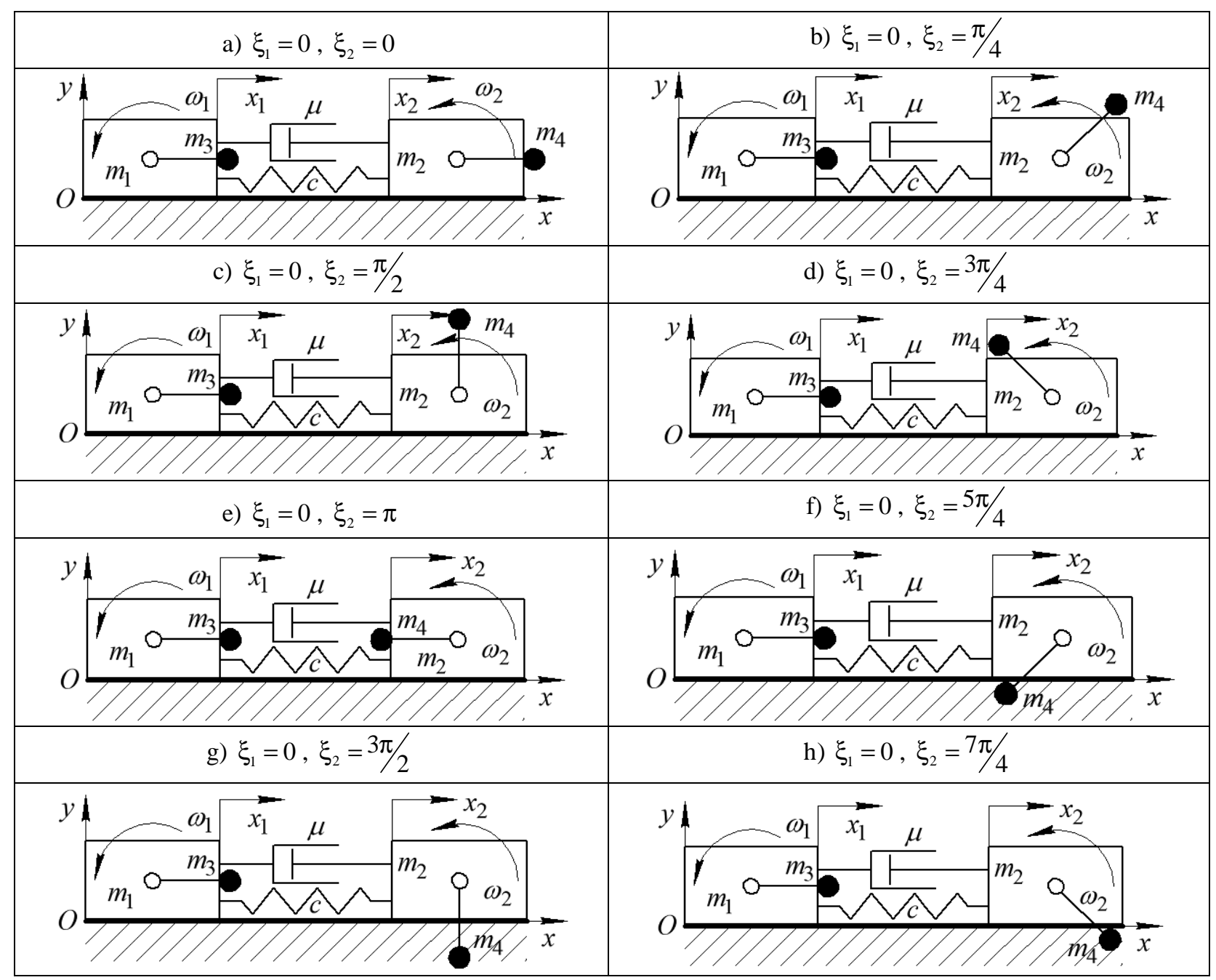


- excitation parameters: $Q_{1 x \max }=Q_{2 x \max }=18,5 \mathrm{H}, \omega_{1}=\omega_{2}=157 \mathrm{rad} / \mathrm{s}(25 \mathrm{~Hz})$;

- initial conditions: initial positions (displacements) of the oscillating masses $x_{1}(0)=0, x_{2}(0)=0$; initial velocity of the oscillating masses $\&(0)=0, \&(0)=0$.

Les us analyse the possibilities of changing the phase shift between the unbalanced masses rotation in order to maximize the speed of the vibratory device motion. Thus, let consider the following phases of the unbalanced masses rotation (Table 1).

The results of modelling the system's motion under different excitation parameters are presented in Fig. 7. By analysing the obtained dependencies, we can make the following conclusions:

- in the cases a) and e), i.e. when $\xi_{1}=0, \xi_{2}=0$ and $\xi_{1}=0, \xi_{2}=\pi$, the vibratory device is not moving translationally (only the masses are oscillating). The average speed of the system's mass centre translational motion equals zero;

- in all the other cases the device will move in different directions and with different speed. In particular, when $\xi_{2}=\pi / 4, \xi_{2}=\pi / 2, \xi_{2}=3 \pi / 4$, i.e. when $0<\xi_{2}<\pi$, the device is moving to the right. When $\xi_{2}=5 \pi / 4, \xi_{2}=3 \pi / 2, \xi_{2}=7 \pi / 4$, i.e. when $\pi>\xi_{2}>2 \pi$, the device is moving in the opposite direction. In the cases when $\xi_{2}=\pi / 4, \xi_{2}=3 \pi / 4, \xi_{2}=5 \pi / 4, \xi_{2}=7 \pi / 4$, the average speed of the system's mass centre translational motion is $0.15 \mathrm{~m} / \mathrm{s}$. When $\xi_{2}=\pi / 2, \xi_{2}=3 \pi / 2$, the average speed of the mass centre is $0.22 \mathrm{~m} / \mathrm{s}$.

By comparing the plots in Fig. 6 and in Fig. 7 (cases c and g), it should be mentioned that the maximal amplitude of displacement of the oscillating mass from the instantaneous equilibrium position corresponds to the theoretically calculated one $\left(X_{1}=X_{2}=0,032 \mathrm{~m}\right)$.

Fig. 8 presents the graphical dependence of changing the average speed of mobile vibratory device under different phases of the unbalanced masses' rotation. By analyzing the obtained plot, we may conclude that the vibratory system is not moving translationally when the unbalanced masses move at the same phase or at the opposite phase. The maximal motion speed of $0.22 \mathrm{~m} / \mathrm{s}$ takes place when the phase shifts are $\xi_{1}=0$, $\xi_{2}=\pi / 2$ and $\xi_{1}=0, \xi_{2}=3 \pi / 2$. The only difference in the system's motion under the considered phase shifts of the unbalanced masses rotation is the direction of the system's motion (to the left or to the right).

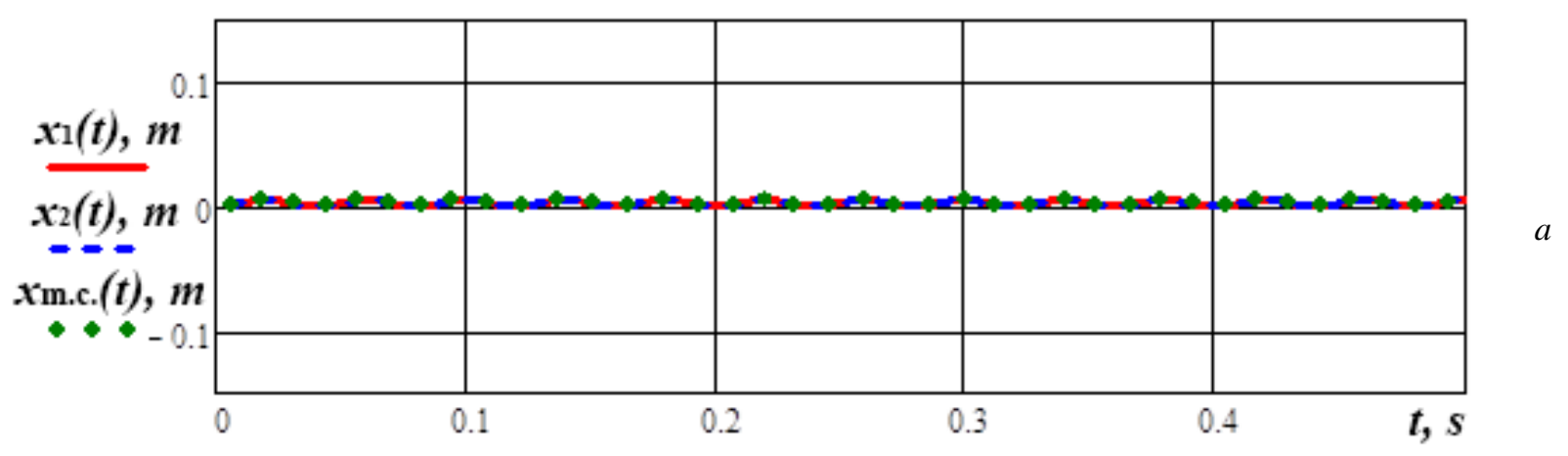

Fig. 7. Time dependencies of displacements of oscillating masses (mass $m_{1}-x_{1}(t)$, mass $\left.m_{2}-x_{2}(t)\right)$ and mass centre of the mechanical system $x_{m . c .}(t)=\left(x_{1}(t)+x_{2}(t)\right) / 2$ under different excitation parameters: plots $a, b, c, d, e, f$, $g, h$-correspond to the phases presented in Table 1

Рис. 7. Часові залежності переміщень коливних мас (маси $m_{1}-x_{1}(t)$, маси $\left.m_{2}-x_{2}(t)\right)$ та иентру мас механічної системи $\left.x_{\text {m.c. }}(t)=\left(x_{1}(t)+x_{2}(t)\right) / 2\right)$ за різних параметрів збурення: графіки $a, b, c, d, e, f, g, h-$ відповідають фазам, наведеним у Таблиці 1 

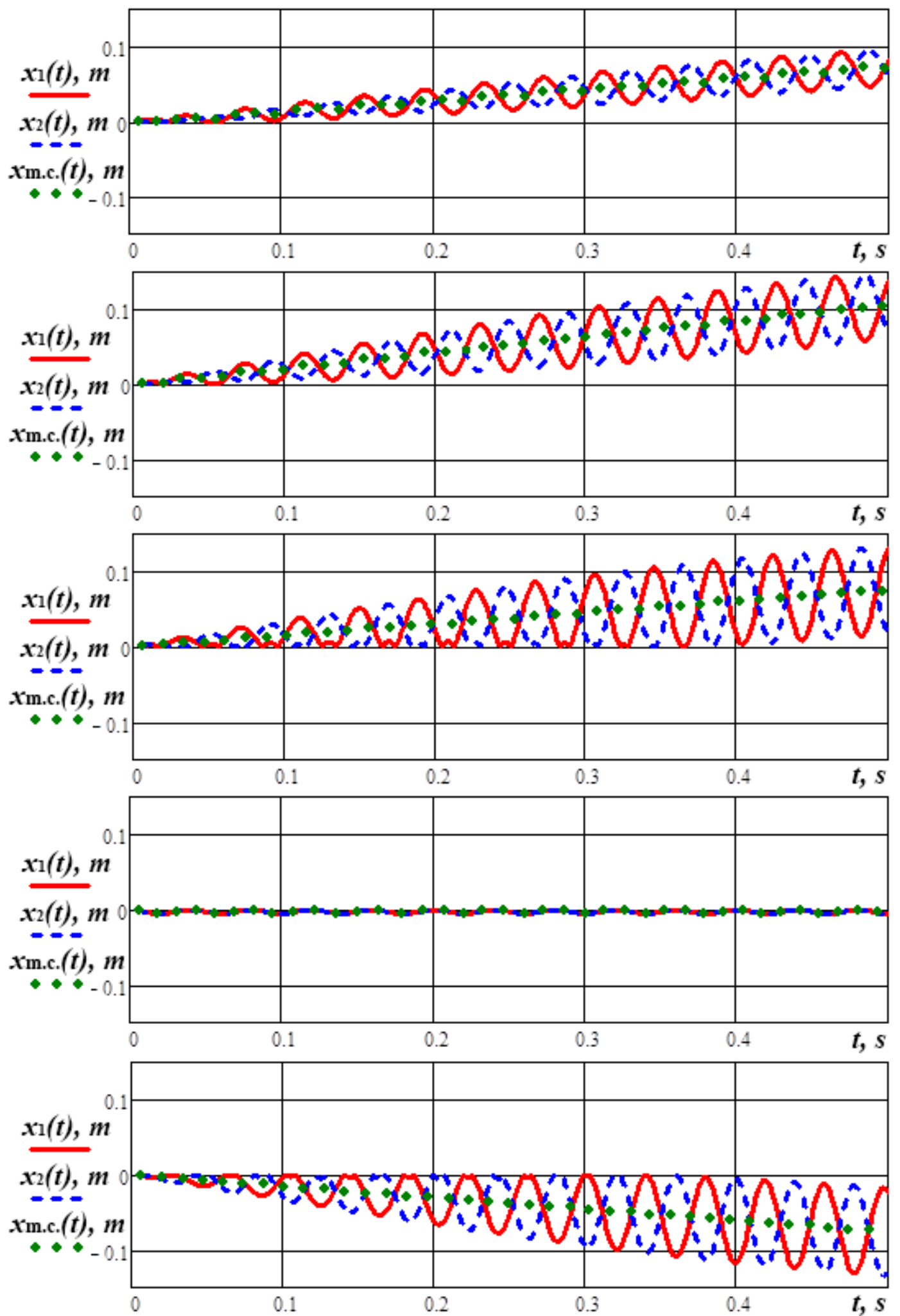

Fig. 7 (continuation). Time dependencies of displacements of oscillating masses (mass $m_{1}-x_{I}(t)$, mass $m_{2}-x_{2}(t)$ ) and mass centre of the mechanical system $x_{m . c .}(t)=\left(x_{1}(t)+x_{2}(t)\right) / 2$ under different excitation parameters: plots $a, b$, $c, d, e, f, g, h$-correspond to the phases presented in Table 1

Рис. 7 (продовження). Часові залежності переміщень коливних мас (маси $m_{1}-x_{1}(t)$, маси $\left.m_{2}-x_{2}(t)\right) m a$ центру мас механічної системи $\left.x_{\text {m.c. }}(t)=\left(x_{1}(t)+x_{2}(t)\right) / 2\right)$ за різних параметрів збурення: графіки $a, b, c, d, e, f$, $g, h$ - відповідають фазам, наведеним у Таблиці 1 


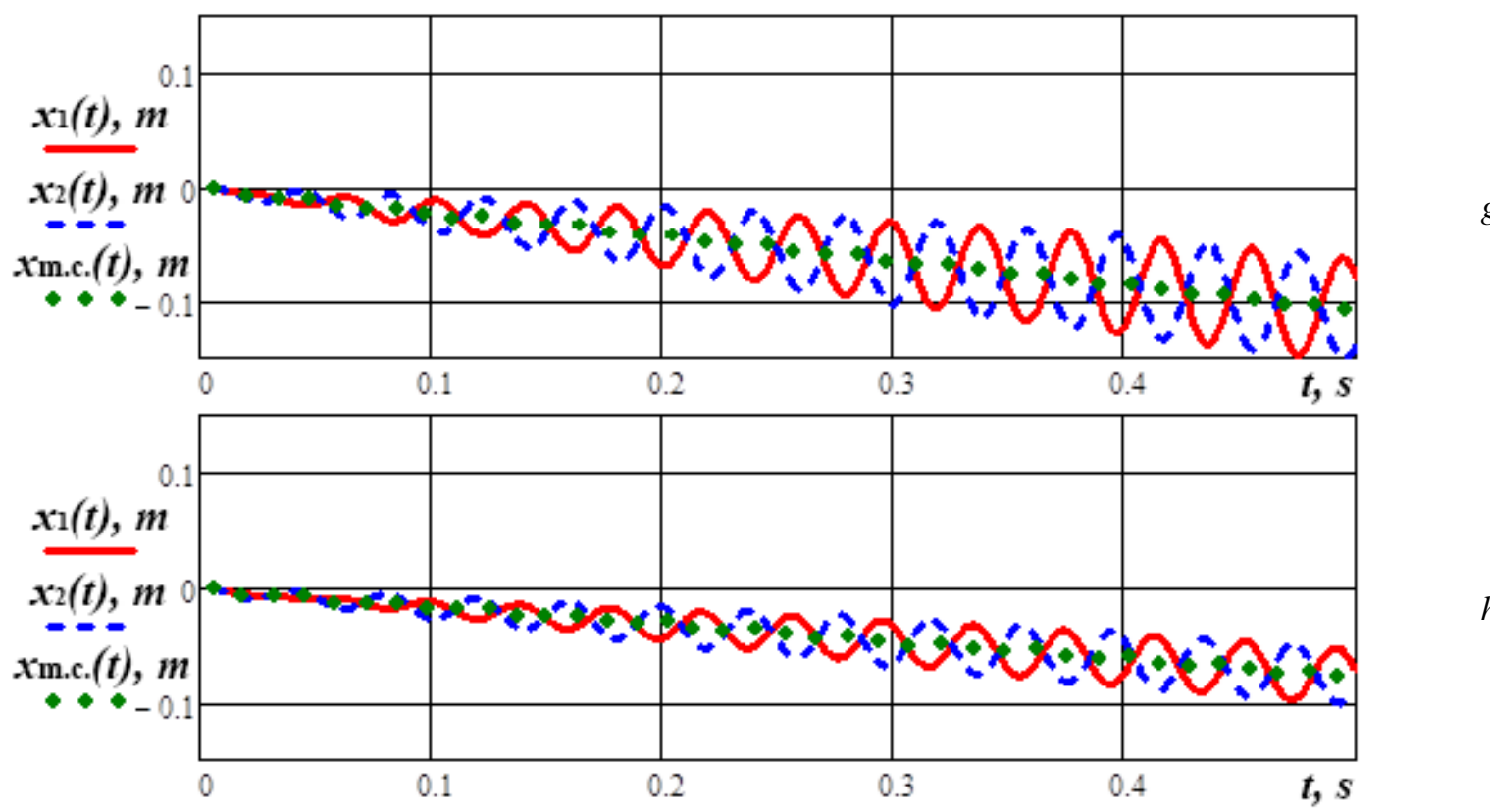

Fig. 7 (continuation). Time dependencies of displacements of oscillating masses (mass $m_{1}-x_{1}(t)$, mass $\left.m_{2}-x_{2}(t)\right)$ and mass centre of the mechanical system $x_{m . c .}(t)=\left(x_{1}(t)+x_{2}(t)\right) / 2$ under different excitation parameters: plots a, $b, c, d, e, f, g, h$-correspond to the phases presented in Table 1

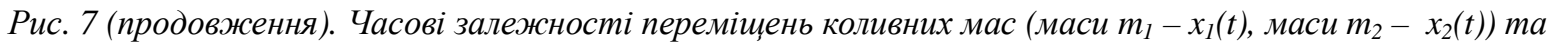
центру мас механічної системи $\left.x_{m . c .}(t)=\left(x_{1}(t)+x_{2}(t)\right) / 2\right)$ за різних параметрів збурення: графіки $a, b, c, d, e$, $f, g, h$ - відповідають фазам, наведеним у Таблиці 1

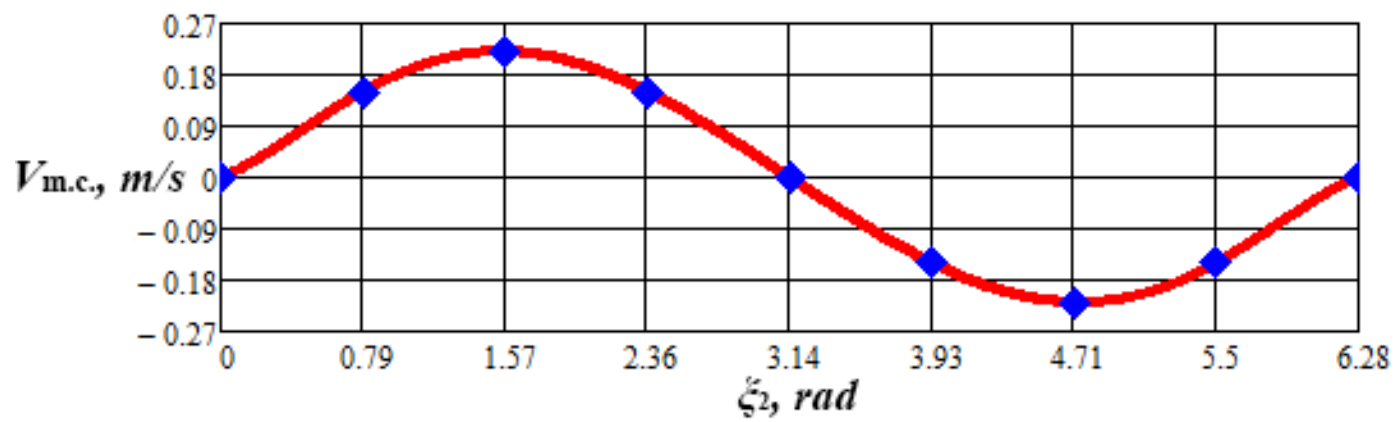

Fig. 8. Dependence of the average motion speed of mobile vibratory system on the phase shift angles of the unbalanced masses' rotation

Рис. 8. Залежність середньої швидкості руху мобільної вібраційної системи від кутів зсуву фаз обертання дебалансів

Conclusions. The structure of the two-mass mobile vibratory system with two unbalanced vibration exciters was analysed, and the corresponding design diagram was constructed. The differential equations of the system's motion were derived. The analytical solving of the obtained linear differential equations with constant coefficients was carried out with a help of the Euler's method. The analytical dependencies for calculating the eigenfrequencies of the system and the amplitudes of the oscillating masses displacements were deduced. The performed theoretical investigations allowed us to substantiate the stiffness parameters of the connecting spring in order to ensure the energy-efficient resonance operation mode. In particular, for the system with following parameters (Fig. 2) $m_{1}=m_{2}=0,25 \mathrm{~kg}, m_{3}=m_{4}=0,025 \mathrm{~kg}, l_{1}=l_{2}=0,03 \mathrm{~m}$, $\omega_{1}=\omega_{2}=25 \mathrm{~Hz}$, there were determined the necessary values of the eigenfrequency $\omega_{0}=26.04 \mathrm{~Hz}$ and the stiffness of the elastic element $c=3680 \mathrm{~N} / \mathrm{m}$. Based on the obtained results, the amplitude-frequency 
characteristic was constructed and the time-dependencies of the excitation force and displacements of the oscillating masses were analysed. It was concluded that the amplitude value of the excitation force of $P_{\max }=18,5 \mathrm{~N}$ causes the maximum displacement of the working body from its equilibrium position of $X=0,032 \mathrm{~m}$.

By solving the derived differential equations of the vibratory system's motion, the influence of the phase shift of the unbalanced masses rotation on the translational speed of the system's mass centre. As a result, it was concluded that the maximal speed of $0.22 \mathrm{~m} / \mathrm{s}$ takes place under the following excitation conditions: $\xi_{1}=0, \xi_{2}=\pi / 2$ and $\xi_{1}=0, \xi_{2}=3 \pi / 2$. The only difference in the system's motion under the considered phase shifts of the unbalanced masses rotation is the direction of the system's motion (to the left or to the right).

In further investigations, it is necessary to analyse the influence of the viscous damping and Coulomb's friction on the system's motion. In addition, the numerical solution of the derived differential equations should be obtained and the motion parameters of the mobile vibratory device should be analysed. In order to substantiate the obtained theoretical results, the experimental investigations should be carried out.

1. N. Bolotnik, I. Zeidis, K. Zimmermann, and S. Yatsun, "Vibration driven robots", in Proc. 5th International Scientific Colloquium "Innovation in Mechanical Engineering - Shaping the Future", Ilmenau University of Technology, Ilmenau, Germany, 12-16 September 2011, pp. 1-6.

2. A. Akbarimajd, and N. Sotoudeh, "Design and motion analysis of vibration-driven small robot Rizeh" Advanced Robotics, Vol. 28, Issue 2, pp. 105-117, 2014.

3. F. Becker, "An Approach to the Dynamics of Vibration-driven Robots with Bristles," IFAC-PapersOnLine, Vol. 48, Issue 1, pp. 842-843, 2015.

4. K. Zimmermann, I. Zeidis, N. Bolotnik, and M. Pivovarov, "Dynamics of a two-module vibration-driven system moving along a rough horizontal plane," Multibody System Dynamics, Vol. 22, Issue 2, pp. 199-219, September 2009.

5. K. Zimmermann, and I. Zeidis, "Dynamical behavior of a mobile system with two degrees of freedom near the resonance," Acta Mechanica Sinica, Vol. 27, Issue 1, pp. 7-17, February 2011.

6. Woong Yeol Joe, "Towards analysis and control of vibration driven robotic mechanism", in Proc. 12th International Conference on Ubiquitous Robots and Ambient Intelligence (URAI), Goyang, South Korea, 28-30 Oct. 2015, pp. 440-443.

7. V. G. Vitliemov, I. V. Ivanov, I. A. Loukanov, "Multi-objective Parametric Syntheses of a Vibrobot," Mechanics of Machines, Vol. 114, Year XXIV, Book 1, pp. 7-13, 2016.

8. A. Kamali Eigoli, G. R. Vossoughi, "Dynamic analysis of vibration-driven systems moving based on frictional locomotion principles," Proceedings of the Institution of Mechanical Engineers, Part C: Journal of Mechanical Engineering Science, Vol. 226, Issue 7, pp. 1787-1799, July 2012.

9. S. Bai, Q. Xu, and Y. Qin, "Vibration driven vehicle inspired from grass spike," Scientific Reports, vol. 3, p. 1851:1-1851:5, May 2013.

10. Singiresu S. Rao, Mechanical Vibrations. Harlow, United Kingdom: Pearson, 2017.

В. М. Корендій

Національний університет "Львівська політехніка"

\section{ОБГРУНТУВАННЯ ПАРАМЕТРІВ ТА МОДЕЛЮВАННЯ РУХУ ДВОМАСОВОЇ МОБІЛЬНОЇ ВІБРАЦЙНОЇ СИСТЕМИ ІЗ ДВОМА ДЕБАЛАНСНИМИ ВІБРОЗБУДНИКАМИ}

(C) Корендій B. М., 2018

Мета дослідження. Аналіз впливу жорсткісних параметрів мобільної вібраційної установки 3 двома дебалансними віброзбудниками на власні частоти іiі механічної коливної системи та обгрунтування жорсткісних параметрів з метою забезпечення енергоефективного резонансного режиму роботи установки. Методи досліджень. Методика досліджень базується на фундаментальних принципах інженерної механіки та теорії механічних коливань. Для виведення диференціальних рівнянь руху механічної системи мобільного 
вібраційного робота використано принцип Даламбера-Лагранжа. Чисельне моделювання руху системи, спричиненого періодично змінними збурювальними силами, здійснювалися за допомогою програмного продукту МathCAD. Результати досліджень. Запропоновано розрахункову схему (модель) двомасової мобільної вібраційної системи із двома дебалансними віброзбудниками. Розроблено математичну модель, яка описує рух системи, та обгрунтовано іiі параметри 3 метою забезпечення резонансного режиму роботи. Зокрема, проаналізовано вплив жорсткості сполучного пружного елемента між робочими тілами мобільної вібраційної установки із двома дебалансними віброзбудниками на власні частоти коливань ії механічної системи, розглянуто усталений та перехідні режими роботи системи за дії періодично змінних збурювальних зусиль. Наукова новизна. Виведено аналітичні залежності для визначення жорсткісних параметрів механічної коливної системи двомасової мобільної вібраційної установки із двома дебалансними віброзбудниками, які забезпечують роботу установки в енергоефективному резонансному режимі. Обгрунтовано величину зсуву фаз обертання дебалансних віброзбудників з метою максимізації швидкості руху установки. Практичне значення роботи. Результати проведених досліджень можна використати в процесі проектування та налагодження систем керування мобільних вібротранспортних і робототехнічних установок з метою забезпечення можливості зміни швидкості їхнього руху без зміни частоти і напрямку обертання дебалансних віброзбудників.

Ключові слова: мобільна вібротранспортна система, віброзбуджувач, резонансний режим роботи, інерційні параметри, жорсткісні параметри, параметри збудження, зсув фаз.

1. N. Bolotnik, I. Zeidis, K. Zimmermann, and S. Yatsun, "Vibration driven robots", in Proc. 5th International Scientific Colloquium "Innovation in Mechanical Engineering - Shaping the Future”, Ilmenau University of Technology, Ilmenau, Germany, 12-16 September 2011, pp. 1-6.

2. A. Akbarimajd, and N. Sotoudeh, "Design and motion analysis of vibration-driven small robot Rizeh," Advanced Robotics, Vol. 28, Issue 2, pp. 105-117, 2014.

3. F. Becker, "An Approach to the Dynamics of Vibration-driven Robots with Bristles," IFAC-PapersOnLine, Vol. 48, Issue 1, pp. 842-843, 2015.

4. S. Bai, Q. Xu, and Y. Qin, "Vibration driven vehicle inspired from grass spike," Scientific Reports, vol. 3, p. 1851:1-1851:5, May 2013.

5. K. Zimmermann, I. Zeidis, N. Bolotnik, and M. Pivovarov, "Dynamics of a two-module vibration-driven system moving along a rough horizontal plane," Multibody System Dynamics, Vol. 22, Issue 2, pp. 199-219, September 2009.

6. K. Zimmermann, and I. Zeidis, "Dynamical behavior of a mobile system with two degrees of freedom near the resonance," Acta Mechanica Sinica, Vol. 27, Issue 1, pp. 7-17, February 2011.

7. Woong Yeol Joe, "Towards analysis and control of vibration driven robotic mechanism", in Proc. 12th International Conference on Ubiquitous Robots and Ambient Intelligence (URAI), Goyang, South Korea, 28-30 Oct. 2015, pp. 440-443.

8. V. G. Vitliemov, I. V. Ivanov, I. A. Loukanov, "Multi-objective Parametric Syntheses of a Vibrobot," Mechanics of Machines, Vol. 114, Year XXIV, Book 1, pp. 7-13, 2016.

9. A. Kamali Eigoli, G. R. Vossoughi, "Dynamic analysis of vibration-driven systems moving based on frictional locomotion principles," Proceedings of the Institution of Mechanical Engineers, Part C: Journal of Mechanical Engineering Science, Vol. 226, Issue 7, pp. 1787-1799, July 2012.

10. Singiresu S. Rao, Mechanical Vibrations. Harlow, United Kingdom: Pearson, 2017. 